\title{
Studi Pola Operasi Pintu Berdasarkan Routing Kapasitas Pengaliran Intake Menara Pada Bendungan Semantok Kabupaten Nganjuk
}

\author{
Siska Rahmadani ${ }^{1 *}$, Rini Wahyu Sayekti ${ }^{2}$, Dian Sisinggih ${ }^{3}$ \\ ${ }^{1}$ Jurusan Teknik Pengairan, Fakultas Teknik, Universitas Brawijaya, \\ Jalan MT. Haryono No. 167, Malang, 65145, INDONESIA \\ *Korespondensi Email : siskarahmadani11@gmail.com
}

\begin{abstract}
Semantok Dam was build to supply water for irrigation with total area of the irrigated is 1825 ha including six weirs (Rejoso weir, Margomulyo weir, Ngomben weir, Jatirejo weir, Janeng weir, and Jati weir) with a minimum requirement of $3,943 \mathrm{~m}^{3} / \mathrm{s}$. To distribute the water for irrigated, so in this study need to use the operating pattern based on the intake routing capacity in main DAM with the intake tower. The operating pattern of the intake door opening needs to be appropriate to prevent problems in water distribution with one-valve and two-valves. The total height loss that happens along intake tower is $6,135 \mathrm{~m}$, here in after used for routing. In operation pattern routing method in one year using one-valve it's fulfill the discharge $83,33 \%$ and with two-valve discharge operation pattern fullfilled $16,67 \%$. Furthermore in the escape channel there's flow affected by the valve, it's sub critical flow and also stilling basin ogee IV.
\end{abstract}

Keywords: Intake, Operating pattern, Routing.

Abstrak: Bendungan Semantok dibangun untuk menyuplai kebutuhan air irigasi seluas 1825 ha meliputi enam bendung (Bendung Rejoso, Bendung Margomulyo, Bendung Ngomben, Bendung Jatirejo, Bendung Janeng, dan Bendung Jati) dengan debit suplai sebesar 3,943 $\mathrm{m}^{3} / \mathrm{dt}$. Guna menyuplai kebutuhan air irigasi, maka dalam studi ini merencanakan pola operasi pintu berdasarkan routing kapasitas intake di bendungan dengan bangunan intake Menara. Pola operasi bukaan pintu intake perlu disesuaikan guna mencegah masalah pendistribusian air dengan bukaan katup yang digunakan 1 (satu) katup dan 2 (dua) katup. Kehilangan tinggi yang terjadi sepanjang intake Menara sebesar 6,135 m yang selanjutnya digunakan untuk melakukan routing. Pada pola operasi metode routing dalam satu tahun menggunakan 1 (satu) katup memenuhi debit suplai sebesar 83,333\% dan pola operasi 2 (dua) katup memenuhi debit suplai $16,667 \%$. Selanjutnya saluran pengarah akhir terdapat aliran yang mempengaruhi setelah pintu katup yaitu aliran sub kritis serta tipe peredam energi ogee IV.

Kata kunci: Intake, Pola operasi, Routing. 


\section{Pendahuluan}

Total keseluruhan daerah irigasi di ndonesia sebesar 6,77 juta ha dan hanya 800.000 ha (kurang dari $15 \%$ ) yang pasokan airnya lebih terjamin melalui waduk sedangkan sisanya sangat bergantung pada ketersediaan air sungai [1]. Bendungan Semantok direncakan menyuplai kebutuhan air irigasi untuk daerah irigasi seluas 1825 ha meliputi 6 bendung diantaranya (Bendung Rejoso, Bendung Margomulyo, Bendung Ngomben, Bendung Jatirejo, Bendung Janeng dan Bendung Jati) dengan debit suplai sebesar $3,943 \mathrm{~m}^{3} / \mathrm{dt}$. Dibangunnya Bendungan Semantok selain untuk menyuplai kebutuhan air irigasi yaitu untuk pengendalian banjir serta air baku. Terkait tujuannya menyuplai kebutuhan air irigasi, diperlukan bangunan intake dimana bangunan intake pada awal konstruksi merupakan bangunan pengelak dan dialih fungsikan pada saat pasca konstruksi. Tipe bangunan intake yang direncanakan merupakan intake Menara dengan 2 konduit saat pra konstruksi dan menjadi 1 konduit saat pasca konstruksi karena debit yang melewai tidak terlalu besar. Guna pemenuhan debit irigasi perlu adanya pola operasi pintu intake yang selanjutnya dilakukan routing untuk mengetahui debit.

Tujuan dari studi ini untuk mengetahui pola operasi bangunan intake menara yang tepat dan sesuai dalam pemenuhan kebutuhan air irigasi dan mendapatkan elevasi muka air pada pada akhir saluran.

\section{Bahan dan Metode}

\subsection{Bahan}

Langkah pengerjaan dalam studi ini untuk dapat menghitung pola operasi dengan menggunakan data seperti data debit andalan, data topografi, lengkung kapasitas waduk, data teknis yang meliputi terowong dan bangunan intake. Untuk data bangunan intake tersaji dibawah ini [2]:

Tipe $\quad$ : Intake menara shaft tenggelam

Panjang saluran intake :186,72 m

Tinggi menara $\quad: 13,64 \mathrm{~m}$

Pintu : katup berjumlah 2 unit

Dimensi katup $\quad$ : Diameter $1,20 \mathrm{~m}$ dengan diameter percabangan $0,90 \mathrm{~m}$

Dimensi konduit $\quad: 3,00 \mathrm{~m}$

El. Tampungan Banjir : $+93,31$

El. Tampungan Normal : $+90,14$

El. Tampungan Mati $\quad:+80,70$

Tampungan Efektif $\quad: 18.303 .262 \mathrm{~m}^{3}$

Tampungan Normal $\quad: 22.404 .068 \mathrm{~m}^{3}$

Tampungan Mati $\quad: 4.100 .806 \mathrm{~m}^{3}$

Debit suplai irigasi $\quad: 3,943 \mathrm{~m}^{3} / \mathrm{dt}$

Total areal irigasi $\quad: 1825$ ha

2.2 Metode

2.2.1 Alur Pengerjaan 


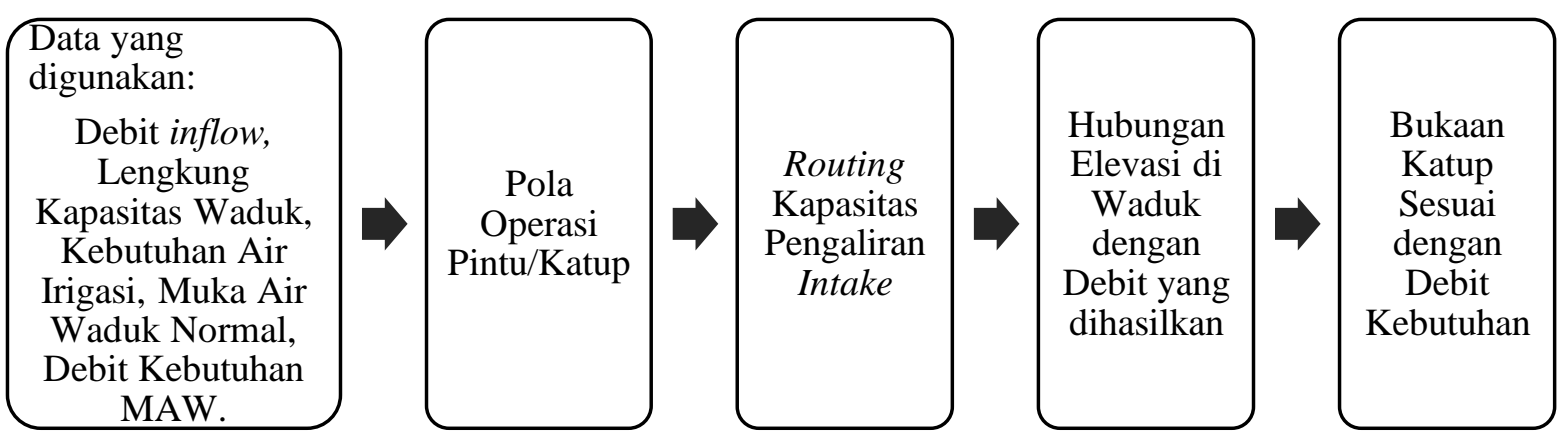

Gambar 1: Alur pengerjaan Pola Operasi Katup

\subsubsection{Hidrolika bangunan Intake pada Menara (Shaft) Tenggelam}

Hidrolika yang digunakan merupakan hidrolika aliran tertutup, berlaku hukum Bernoulli, menggunakan persamaan berikut [3]:

$$
H T=h_{L}+h c \quad \text { Pers. } 1
$$

Dengan:

$\mathrm{H}_{\mathrm{T}} \quad=$ Total head

$\mathrm{h}_{\mathrm{L}} \quad=$ Kehilangan tinggi tekan kumulatif

$\mathrm{h}_{\mathrm{C}} \quad=$ Kehilangan tinggi tekan akibat kontraksi

2.2.3 Kehilangan Tinggi Pada Bangunan Pengambilan (Intake) [4]

Kehilangan akibat melewati penangkap sampah (Trashrack Loss)

$$
h t=k t \cdot \frac{\bar{v}^{2}}{2 \cdot g} \quad \text { Pers. } 2
$$

Kehilangan akibat melewati pintu masuk (Entrance Loss)

$$
h e=k e \cdot \frac{\bar{v}^{2}}{2 \cdot g} \quad \text { Pers. } 3
$$

Kehilangan akibat gesekan (Friction Loss) pada shaft

Rumus untuk pipa bundar:

$$
h f=f \cdot \frac{L \cdot v^{2}}{d \cdot 2 g} \quad \text { Pers. } 4
$$

Rumus untuk pipa tidak bundar:

$$
h f=f \cdot \frac{L \cdot v^{2}}{4 R \cdot 2 g} \quad \text { Pers. } 5
$$

Kehilangan akibat perubahan bentuk (Expantion Loss)

$$
h t=k e x \cdot \frac{\bar{v}^{2}}{2 \cdot g} \quad \text { Pers. } 6
$$

Kehilangan akibat perubahan bentuk (Sudden Construction Loss)

$$
h s c=k s c \cdot \frac{\bar{v}^{2}}{2 \cdot g} \quad \text { Pers. } 7
$$

Kehilangan akibat belokan 


$$
h b=k b \cdot \frac{\bar{v}^{2}}{2 \cdot g} \quad \text { Pers. } 8
$$

Kehilangan tinggi akibat valve

$$
h v=k v \cdot \frac{\bar{v}^{2}}{2 \cdot g} \quad \text { Pers. } 9
$$

Kehilangan tinggi akibat pipa bercabang [5]

$$
h_{L a}=k a \cdot \frac{\bar{v}^{2}}{2 \cdot g} \quad \text { Pers. } 10
$$

Dengan:

$$
\begin{aligned}
\mathrm{ht} & =\text { trashrack losses, } \\
\mathrm{he} & =\text { entrance losses, } \\
\mathrm{hb} & =\text { bend losses, } \\
\mathrm{hf} & =\text { friction losses } \\
\mathrm{hex} & =\text { expansion losses, } \\
\mathrm{hc} & =\text { contraction losses, } \\
\mathrm{hg} & =\text { gate or valve losses, and } \\
\mathrm{hv} & =\text { velocity head exit loss at the outlet. }
\end{aligned}
$$

\subsubsection{Routing Pola Operasi Katup}

Aliran pembawa akan dikeluarkan melalui fasilitas pengeluaran yang terdiri dari katup yang mengatur debit pengeluaran untuk memenuhi kebutuhan pada daerah hilir bendungan. Sesuai dengan fungsi dari bangunan pengambilan yaitu mengatur debit yang harus dikeluarkan maka besarnya debit aliran yang akan keluar dihitung dengan persamaan berikut [3]:

$$
Q=C \cdot A \cdot \frac{\sqrt{2 g H}}{\sum H_{T}} \quad \text { Pers. } 11
$$

Nilai $\mathrm{C}$ ditentukan berdasarkan syarat koefisien debit untuk kondisi aliran bebas adalah y3/y1 $\leq$ 0,67 , untuk kondisi aliran terendam dengan syarat $0,67<\mathrm{y} 3 / \mathrm{y} 1<0,80$ dan untuk kondisi aliran terendam penuh dengan syarat $\mathrm{y} 3 / \mathrm{y} 1 \geq 0,80[6]$.

Dari persamaan rumus diatas untuk mendapatkan debit yang diharapkan diperlukan menghitung luasan pipa (A) dan tinggi air $(\mathrm{H})$ dengan persamaan [3]:

$$
\begin{aligned}
& A=\frac{\pi \cdot d^{2}}{4} \quad \text { Pers. } 12 \\
& H=\Sigma H t \cdot \frac{v^{2}}{2 \cdot g} \quad \text { Pers. } 13
\end{aligned}
$$

Dengan:

$\mathrm{Q}=\operatorname{Debit}\left(\mathrm{m}^{3} / \mathrm{dt}\right)$

$\mathrm{C} \quad=$ Koefisien debit

A $=$ Luas penampang $\left(\mathrm{m}^{2}\right)$

$\pi \quad=$ Jari-jari lingkaran 
$\mathrm{d}=$ Diameter lingkaran

$\mathrm{H} \quad=$ Tinggi air di waduk $(\mathrm{m})$

$\Sigma \mathrm{H}_{\mathrm{T}}=$ Total koefisien kehilangan tinggi

$\mathrm{v} \quad=\operatorname{Kecepatan}(\mathrm{m} / \mathrm{dt})$

$\mathrm{g} \quad=$ Percepatan gravitasi $\left(9,81 \mathrm{~m} / \mathrm{dt}^{2}\right)$

\subsubsection{Perhitungan Saluran Pengarah Akhir}

\subsubsection{Peredam Energi}

Kolam olak merupakan suatu konstruksi yang berfungsi sebagai peredam energi yang terkandung dalam aliran dengan memanfaatkan loncatan hidrolis dari suatu aliran yang berkecepatan tinggi. Dalam menentukan kolam olak menggunakan tinggi hidrolis dapat menggunakan rumus sebagai berikut [7]:

Kedalaman air pada bagian udik dan hilir loncatan hidrolis

$$
\frac{Y 1}{Y 2}=\frac{1}{2}\left(\sqrt{1+8 F r_{1}^{2}}-1\right) \quad \text { Pers. } 14
$$

Bilangan Froude

$$
F r_{1}=\frac{v}{\sqrt{g Y 1}} \quad \text { Pers. } 15
$$

Panjang loncatan hidrolis

$$
X=5(Y 3+\Delta z) \quad \text { Pers. } 16
$$

Dengan:

$\mathrm{Y}_{1} \quad=$ kedalaman air awal loncatan

$\mathrm{Y}_{2} \quad=$ kedalaman air di atas ambang

$\mathrm{v} \quad=$ kecepatan aliran $(\mathrm{m} / \mathrm{dt})$

Fr $\quad=$ bilangan Froude

g = percepatan gravitasi $\left(9,81 \mathrm{~m} /\right.$ detik $\left.^{2}\right)$

$\mathrm{Y}_{3}=$ kedalaman air normal di hilir loncat air

$\Delta \mathrm{z} \quad=$ tinggi kenaikan dasar saluran

\subsubsection{Escape Channel}

Saluran ini merupakan saluran penghubung antara ujung hilir, peredam energi dengan sungai. Untuk menentukan dimensi dan nilai $\mathrm{Y}_{3}$ menggunakan persamaan sebagai berikut [8]:

$$
Q=A^{1 / n} R^{2} / 3 S^{1 / 2} \quad \text { Pers. } 17
$$

Dengan:

$\mathrm{Q} \quad=$ Debit keluaran maksimum $\left(\mathrm{m}^{3} /\right.$ detik $)$

A $\quad=$ Luas saluran $\left(\mathrm{m}^{2}\right)$

$\mathrm{n} \quad=$ Koefisien Manning 
$\mathrm{R} \quad=$ Jari-jari hidrolis

$\mathrm{Tc} \quad=$ Waktu konsentrasi (jam)

$\mathrm{S} \quad=$ Kemiringan dasar saluran (slope)

\subsubsection{Perhitungan Water Hammer}

Pukulan air (water hammer) merupakan air yang mengalir dalam suatu pipa yang membuat rangkaian gelombang tekanan positif dan negatif akan bergerak maju mundur dalam terowong sampai terhenti oleh gesekan [9].

Kecepatan perambatan tekanan pada gelombang (c) dalam terowong tekan tergantung pada modulus elastisitas air (Eb) dan modulus elastisitas materal dinding terowong tekan (Ep) yang hubungannya dinyatakan dengan persamaan berikut [10]:

$$
\begin{gathered}
c=\sqrt{\frac{E c}{\rho}} \quad \text { Pers.18 } \\
\frac{1}{E c}=\frac{1}{E b}+\frac{D}{E p \cdot \omega} \quad \text { Pers. } 19
\end{gathered}
$$

Dengan:

$\mathrm{c} \quad=$ kecepatan perambatan tekanan gelombang

$\rho \quad=$ Rapat massa air

$\mathrm{Ec} \quad=$ Campuran antara Ep dan $\mathrm{Eb}$

$\mathrm{Eb} \quad=$ Modulus elastisitas jumlah besar

Ep $\quad=$ Modulus elastisitas material dinding terowong tekan

$\omega=$ ketebalan dinding pipa

\subsubsection{Ventilasi}

Ventilasi sebagai pembuang udara yang terkurung oleh loncatan hidrolis aliran air di dalam terowong/ pipa penyalur. Saat mulai dibuka sampai terbuka penuh udara terdorong keluar melalui pipa ventilasi [8].

Volume udara yang dibutuhkan

$$
\frac{Q a}{Q w}=0,04(F r-1)^{0,85} \quad \text { Pers. } 20
$$

Dengan:

$\mathrm{Qa} \quad=$ Volume udara yang dibutuhkan

$\mathrm{Qw}=$ Debit air pada saat pintu/katup dibuka $80 \%\left(\mathrm{~m}^{3} /\right.$ detik $)$

Fr $\quad=$ Bilangan Froude dari aliran air super kritis persis di belakang pintu/katup

Untuk pipa penyalur yang kecil dengan ventilasi yang kecil pula, maka untuk menghitung volume udara yang dibutuhkan diambil 15\% dari kapasitas pengambilan maksimum bangunan pengambilannya. 


\section{Hasil dan Pembahasan}

\subsection{Kehilangann Tinggi Pengambilan Intake Menara}

Kehilangan tinggi terjadi pada sepanjang pipa, dari mulai mulut pemasukan pipa (entrance) sampai dengan pipa pengeluaran (outlet). Hasil kehilangan tinggi pada bangunan intake pengambilan tersaji pada tabel 1.

Tabel 1: Rekapitulasi Hasil Kehilangan Tinggi Sepanjang Pipa

\begin{tabular}{cc}
\hline \multicolumn{2}{c}{ Hasil Perhitungan } \\
\hline Ht I & $0.465 \mathrm{~m}$ \\
Ht II & $0.657 \mathrm{~m}$ \\
Ht III & $2.584 \mathrm{~m}$ \\
Ht IV & $2.429 \mathrm{~m}$ \\
\hline LHt & $6.135 \mathrm{~m}$ \\
\hline
\end{tabular}

Berdasarkan tabel 1 tersaji hasil perhitungan kehilangan tinggi yang terjadi sepanjang pipa yaitu nilai kehilangan tinggi total sebesar 6,135 m. Untuk lebih detailnya dapat dilihat pada gambar 2 .

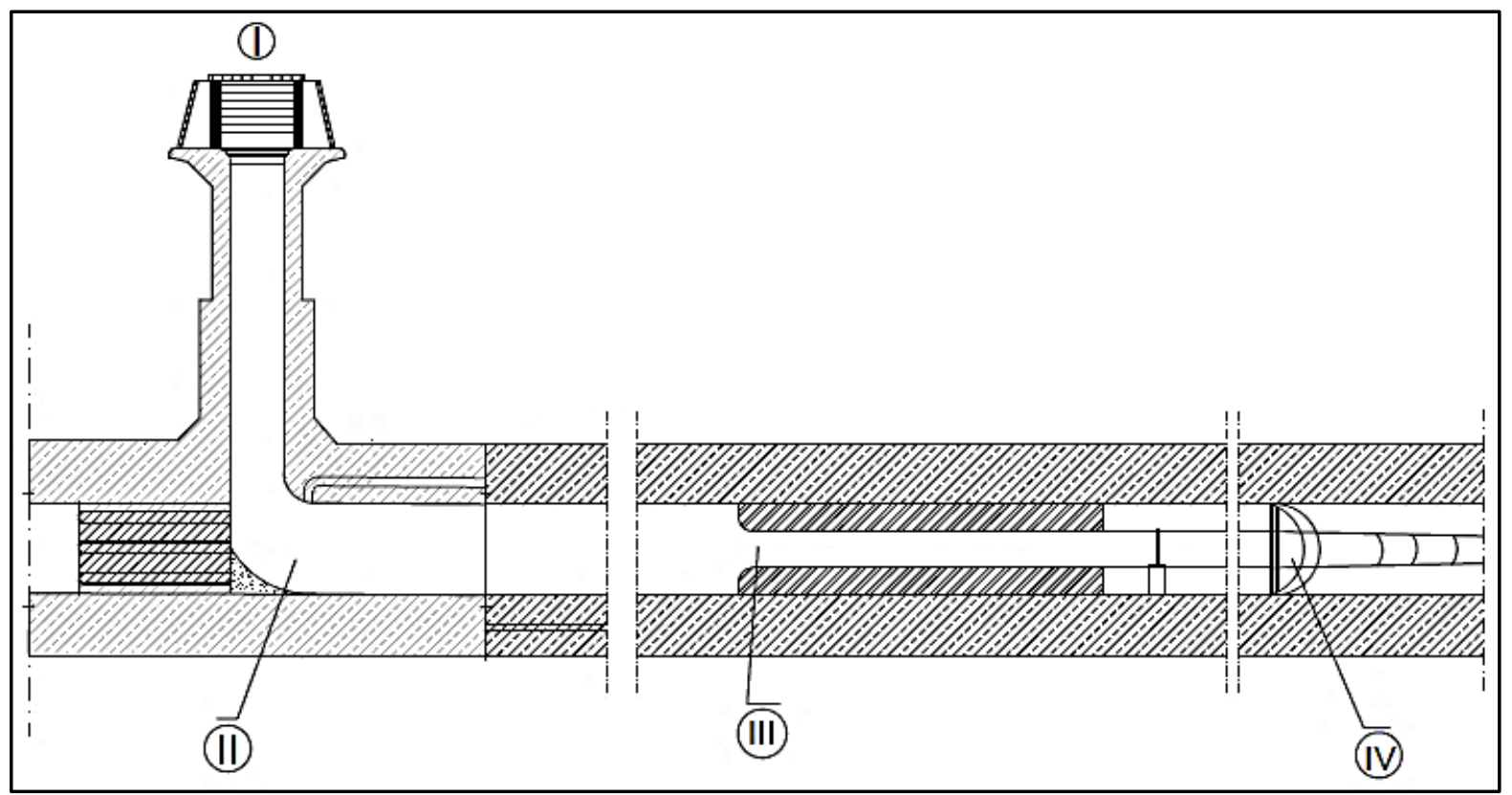

Gambar 2: Potongan Memanjang Beserta pembagian Lokasi Perhitungan Kehilangan Tinggi

Pada gambar $2 \mathrm{Ht}$ (kehilangan tinggi) di bagi menjadi 4 bagian dengan:

Bagian I $\quad$ : Kehilangan Tinggi Tekan Akibat Kisi Saringan (ht) + Lubang Pemasukan (he) + Gesekan Sepanjang Menara $\left.\left(\mathrm{hf}_{1}\right)\right)$

Bagian II : (Kehilangan Tinggi Tekan Akibat Belokan $\left(\mathrm{hb}_{1}\right)+$ Perubahan Bentuk/Expansion Loss (hex) + Gesekan Sepanjang Konduit $\left(\mathrm{hf}_{2}\right)$ )

Bagian III : (Kehilangan Tinggi Tekan Akibat Gesekan Perbedaan Pipa Konduit dan Pipa Pengeluaran $\left(\mathrm{hf}_{3}\right)+$ Sudden Construction Loss $(\mathrm{hsc})+$ Katup $(\mathrm{hg})+$ Kehilangan Tinggi Tekan Akibat Belokan $\left(\mathrm{hb}_{2}+\mathrm{hb}_{3}\right)$ )

Bagian IV : (Pipa Bercabang $\left(\mathrm{h}_{\mathrm{La}}\right)+$ Katup $(\mathrm{hg})+$ Outlet $\left.(\mathrm{ho})\right)$

\subsection{Perhitungan Pola Operasi Kapasitas Pengaliran Intake}

Berdasarkan data [2] diketahui debit suplai maksimal untuk mengairi total daerah irigasi 1825 ha adalah sebesar 3,943 $\mathrm{m}^{3} / \mathrm{dt}$. Dengan mempertimbangkan hal tersebut maka perlu di cek melalui 
kapasitas pengaliran pada kondisi tekan menggunakan Metode routing, maka diperoleh pola operasi 1 (satu) dan 2 (dua) katup yang tersaji pada tabel dibawah ini.

Tabel 2: Pola operasi Debit Pengambilan Intake 1 (satu) Katup untuk 1825 ha

\begin{tabular}{|c|c|c|c|c|c|c|c|c|c|}
\hline \multirow[t]{2}{*}{ Elevasi } & $\begin{array}{c}\text { H inlet } \\
\text { outlet }\end{array}$ & $\Sigma \mathrm{Ht}$ & $\mathrm{g}$ & C & V & A & Q & $\begin{array}{c}\text { Q } \\
\text { suplai }\end{array}$ & \multirow[t]{2}{*}{ Keterangan } \\
\hline & (m) & & $\left(\mathrm{m} / \mathbf{d t}^{2}\right)$ & & $(\mathbf{m} / \mathbf{d t})$ & $\left(\mathbf{m}^{2}\right)$ & $\left(\mathrm{m}^{3} / \mathbf{d t}\right)$ & $\left(\mathrm{m}^{3} / \mathrm{dt}\right)$ & \\
\hline+90.14 & 23.480 & 6.135 & 9.810 & .800 & 8.665 & 0.636 & $\begin{array}{l}4.409 \\
\end{array}$ & 3.943 & nuhi \\
\hline+89.14 & 22.480 & & & & & 0.636 & & 3.943 & \\
\hline+88.14 & 21.4 & & & & & & & 3.943 & \\
\hline+87.14 & 20.480 & 6 & & 80 & 8.0 & & 41 & 3.943 & \\
\hline+86.14 & 19.480 & 6.135 & 9.810 & 0.800 & 7.893 & 0.636 & 4.016 & 3.943 & \\
\hline+85.14 & 18.480 & 6.13 & 9.810 & 0.800 & 7.688 & 0.636 & 3.911 & 3.943 & $\begin{array}{r}\text { Tidak memenuhi } \\
14.819 \text { ha }\end{array}$ \\
\hline+84.14 & 17.480 & 6.135 & 9.810 & 0.800 & 7.477 & 0.636 & 3.804 & 3.943 & $\begin{array}{r}\text { Tidak memenuhi } \\
64.331 \text { ha }\end{array}$ \\
\hline+83.14 & 16.480 & 6.135 & 9.810 & 0.800 & 7.260 & 0.636 & 3.694 & 3.943 & $\begin{array}{r}\text { Tidak memenuhi } \\
115.249 \text { ha }\end{array}$ \\
\hline+8 & 15.480 & 6 & 9 & 0 & 7 & 6 & 3.580 & 3.943 & $\begin{array}{r}\text { Tidak memenuhi } \\
168.009 \text { ha }\end{array}$ \\
\hline+80.70 & 13.640 & 6.135 & 9.810 & 0.800 & 6.605 & 0.636 & 3.360 & 3.943 & $\begin{array}{r}\text { Tidak memenuhi } \\
269.845 \text { ha }\end{array}$ \\
\hline
\end{tabular}

Tabel 3: Pola operasi Debit Pengambilan Intake 2 (dua) Katup untuk 1825 ha

\begin{tabular}{|c|c|c|c|c|c|c|c|c|c|}
\hline \multirow{2}{*}{ Elevasi } & $\begin{array}{c}\mathrm{H} \text { inlet } \\
\text { outlet }\end{array}$ & $\Sigma \mathrm{Ht}$ & $\mathrm{g}$ & C & V & A & Q & Q suplai & \multirow[t]{2}{*}{ Keterangan } \\
\hline & (m) & & $\left(\mathrm{m} / \mathrm{dt}^{2}\right)$ & & $(\mathrm{m} / \mathrm{dt})$ & $\left(\mathbf{m}^{2}\right)$ & $\left(\mathrm{m}^{3} / \mathrm{dt}\right)$ & $\left(\mathrm{m}^{3} / \mathrm{dt}\right)$ & \\
\hline+90.14 & 23.480 & 6.135 & 9.810 & 0.800 & 8.665 & 1.272 & 8.818 & 3.943 & Memenuhi \\
\hline+89.14 & 22.480 & 6.135 & 9.810 & 0.800 & 8.479 & 1.272 & 8.628 & 3.943 & Memenuhi \\
\hline+88.14 & 21.480 & 6.135 & 9.810 & 0.800 & 8.2 & 1.272 & 8.434 & 3.943 & Memenuhi \\
\hline+87.14 & 20.480 & 6.135 & 9.810 & 0.800 & 8.093 & 1.272 & 8.235 & 3.943 & Memenuhi \\
\hline+86.14 & 19.480 & 6.135 & 9.810 & 0.800 & 7.893 & 1.272 & 8.032 & 3.943 & Memenuhi \\
\hline+85.14 & 18.480 & 6.135 & 9.810 & 0.800 & 7.688 & 1.272 & 7.823 & 3.943 & Memenuhi \\
\hline+84.14 & 17.480 & 6.13 & 9.810 & 0.800 & 7. & 1. & 7.608 & 3.943 & Memenuhi \\
\hline+83.14 & 16.480 & 6.135 & 9.810 & 0.800 & 7.260 & 1.272 & 7.388 & 3.943 & Memenuhi \\
\hline+82.14 & 15.480 & 6.135 & 9.810 & 0.800 & 7.036 & 1.272 & 7.160 & 3.943 & Memenuhi \\
\hline+80.70 & 13.640 & 6.135 & 9.810 & 0.800 & 6.605 & 1.272 & 6.721 & 3.943 & Memenuhi \\
\hline
\end{tabular}

Berdasarkan hasil analisis pola operasi 1 (satu) katup terdapat beberapa debit yang tidak mampu mengairi total luasan daerah irigasi dan pola operasi 2 (dua) katup dapat memenuhi seluruhnya kebutuhan irigasi.

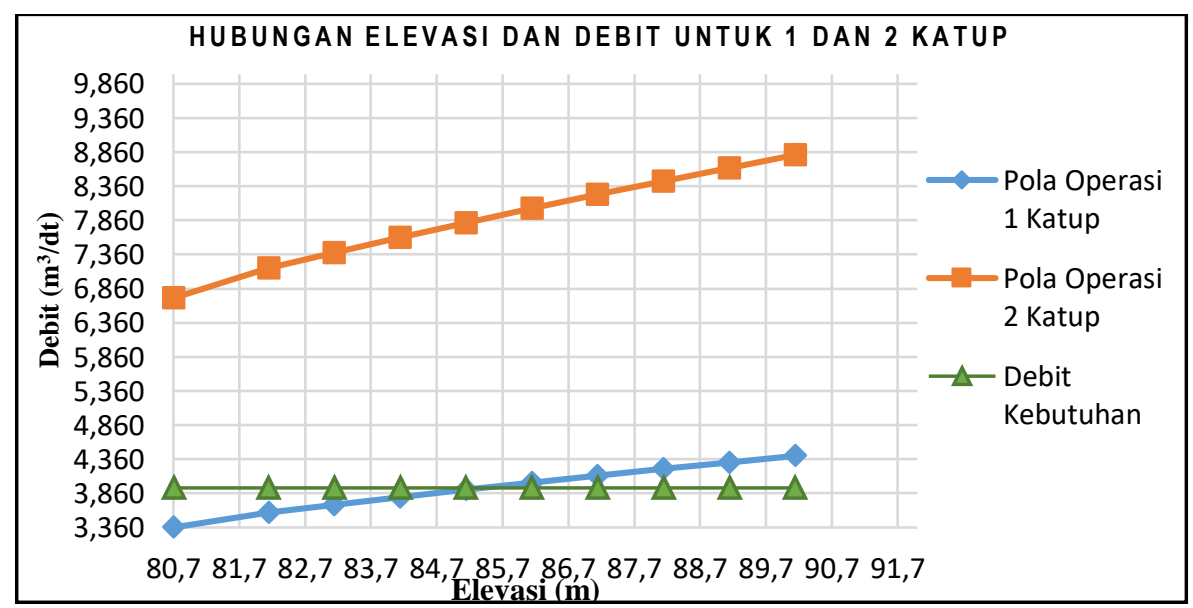

Gambar 3: Hubungan Elevasi dan Debit untuk 1 (satu) dan 2 (dua) Katup 
Gambar 3 merupakan kurva hubungan elevasi dan debit untuk 1 (satu) dan 2 (dua) katup dengan debit ketika bukaan 1 katup ada yang memenuhi dan tidak dinyatakan dengan warna biru. Sedangkan debit kebutuhannya sendiri dinyatakan dengan warna hijau. Maka, untuk bukaan 2 katup dengan dinyatakan pada warna orange dapat memenuhi debit kebutuhan seluruhnya.

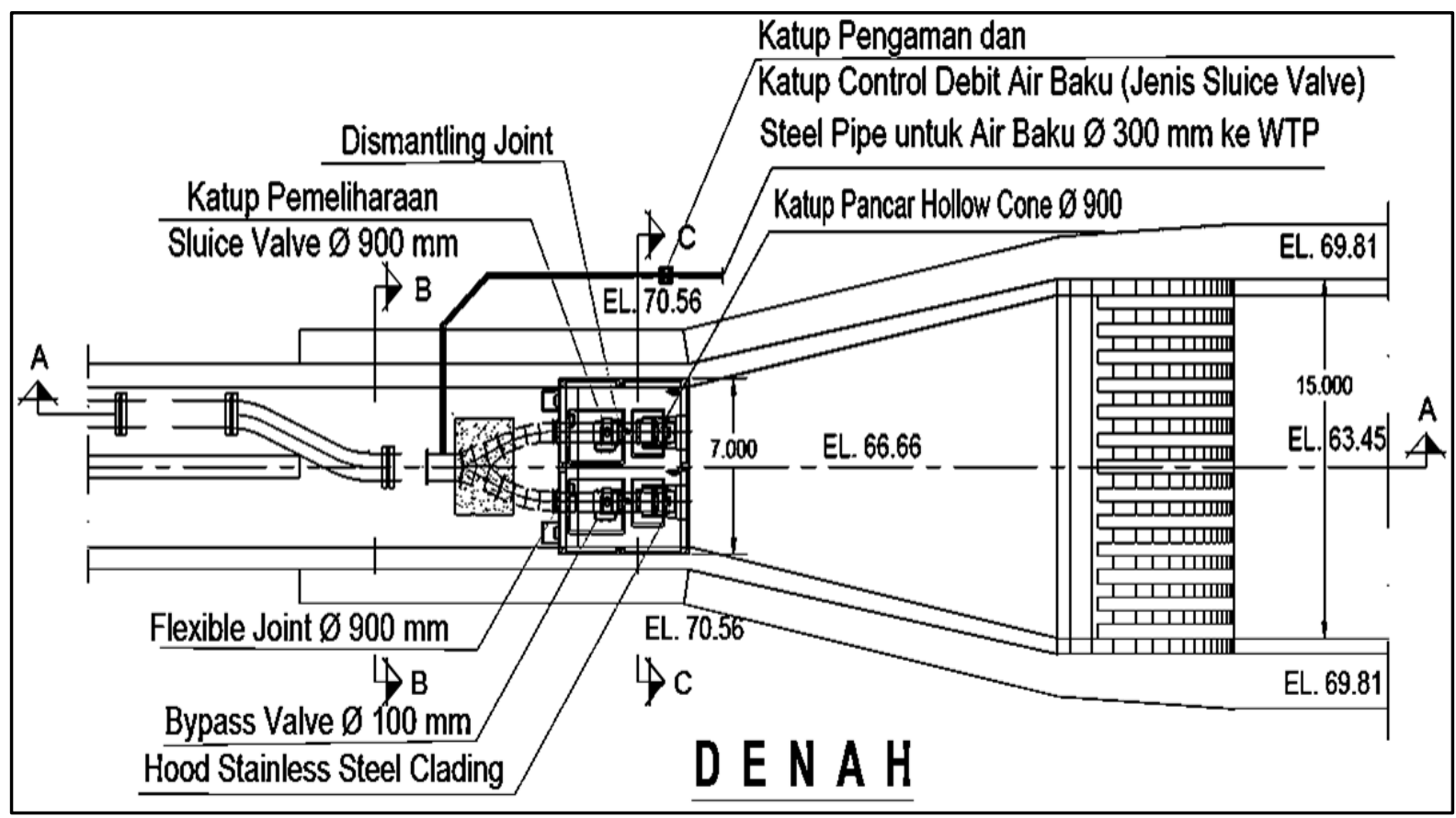

Gambar 4: Denah Rumah Katup

Gambar 4 merupakan denah katup dimana dapat dilihat bahwa terdapat 2 katup sesuai dengan pola operasi yang di lakukan. Selain itu katup yang digunakan adalah katup hollow cone valve dengan sistem buka tutup pintunya secara otomatis.

\subsection{Pola Operasi 1 (Satu) Tahun dengan 1 (Satu) dan 2 (Dua) Katup}

Dari pola operasi diatas di dapatkan debit berdasarkan metode routing untuk setiap ketinggiannya. Maka, dibutuhkan pola operasi 'dalam 1 (satu) tahun dengan bukaan katup yang disesuaikan dengan kebutuhan, yang tersaji pada tabel 4.

Tabel 4: Pola Operasi dalam 1 Tahun dengan 1 (Satu) dan 2 (Dua) Katup

\begin{tabular}{lccc}
\hline \multicolumn{1}{c}{ Bulan } & $\begin{array}{c}\text { Total Suplai } \\
\mathrm{lt} / \mathrm{dt}\end{array}$ & $\begin{array}{c}\text { Total Suplai } \\
\mathrm{m}^{3} / \mathrm{dt}\end{array}$ & Bukaan Katup \\
\hline \hline Januari & 4146.452 & 4.146 & 1 Katup \\
Februari & 2025.082 & 2.025 & 1 Katup \\
Maret & 2200.529 & 2.201 & 1 Katup \\
April & 3671.274 & 3.671 & 1 Katup \\
Mei & 7362.815 & 7.363 & 2 Katup \\
Juni & 6772.753 & 6.773 & 2 Katup \\
Juli & 1396.302 & 1.396 & 1 Katup \\
Agustus & 1592.195 & 1.592 & 1 Katup \\
September & 3231.147 & 3.231 & 1 Katup \\
Oktober & 3348.750 & 3.349 & 1 Katup \\
Nopember & 2807.334 & 2.807 & 1 Katup \\
Desember & 3377.047 & 3.377 & 1 Katup \\
\hline
\end{tabular}


Berdasarkan hasil analisis pola operasi diatas diperoleh debit yang bervariatif pada masing-masing bulan. Penentuan menggunakan 1 (satu) dan 2 (dua) katup dilakukan dengan melihat debit dalam 1 tahun memenuhi atau tidak untuk debit 1 (satu) katup 4,409 $\mathrm{m}^{3} / \mathrm{dt}$ dan 2 (dua) katup 8,818 $\mathrm{m}^{3} / \mathrm{dt}$. Jika memenuhi untuk 1 (satu) katup maka akan dibuka untuk 1 (satu) katup namun jika 1 (satu) katup tidak dapat memenuhi maka akan dibuka dengan 2 (dua) katup. Dapat disimpulkan bahwa hanya pada bulan Mei dan Juni saja yang menggunakan 2 (dua) katup dengan presentase 16,667\% dan pada bulan lainnya menggunakan 1 (satu) katup dengan presentase 83,333\%.

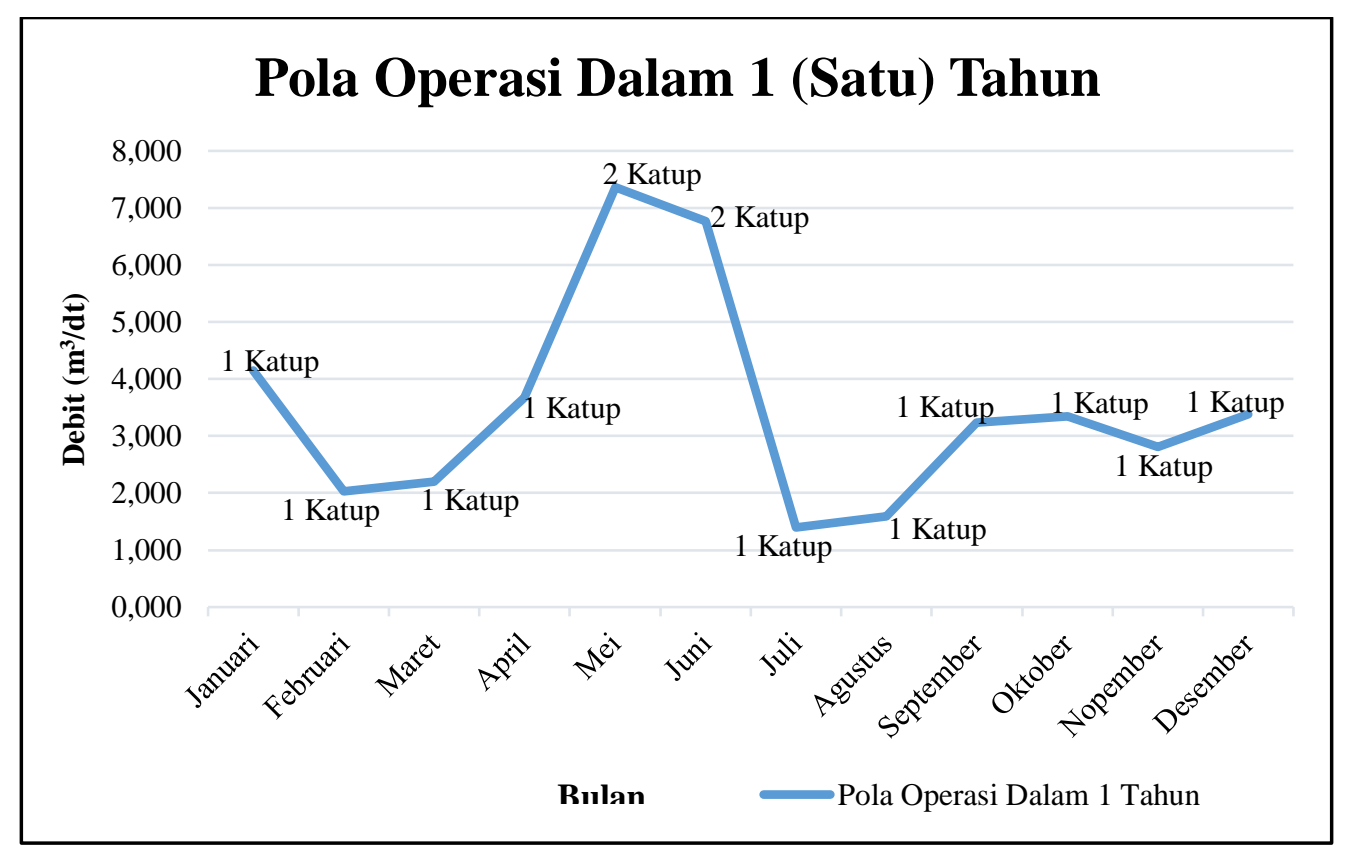

Gambar 5: Pola Operasi Dalam 1 Tahun dengan 1 (Satu) dan 2 (Dua) Katup

Berdasarkan gambar 5 dinyatakan bahwa pola operasi 1 tahun dengan variasi debit setiap bulannya diperoleh hanya pada bulan Mei dan Juni yang menggunakan 2 Katup.

\subsection{Perhitungan Kelebihan dan Kekurangan Debit Pada Pola Operasi 1 (Satu) dan 2 (Dua) Katup}

Setelah mengetahui variasi debit dalam 1 tahun, maka dapat dihitung kelebihan dan kekurangan debit setiap bulannya dengan debit hasil routing pola operasi 1 (satu) dan 2 (dua) katup, tersaji pada tabel 5 dan 6.

Tabel 5: Rekapitulasi Kelebihan dan Kekurangan Debit Dalam 1 Tahun Untuk 1 (Satu) Katup

\begin{tabular}{|c|c|c|c|c|c|c|c|}
\hline \multirow[b]{2}{*}{ Elevasi } & \multirow{2}{*}{$\begin{array}{c}\text { Debit } \\
\text { Hitung } \\
\text { Intake } 1 \\
\text { Katup } \\
\mathrm{m}^{3} / \mathrm{dt}\end{array}$} & \multicolumn{2}{|c|}{$\begin{array}{c}\text { Januari : } \\
4,146 \mathrm{~m}^{3} / \mathrm{dt}\end{array}$} & \multicolumn{2}{|c|}{$\begin{array}{c}\text { Februari: } \\
2,025 \mathrm{~m}^{3} / \mathrm{dt}\end{array}$} & \multicolumn{2}{|c|}{$\begin{array}{c}\text { Maret: } \\
2,201 \mathrm{~m}^{3} / \mathrm{dt}\end{array}$} \\
\hline & & $\begin{array}{c}\text { Kekurangan } \\
\text { Debit } \\
\mathrm{m}^{3} / \mathrm{dt}\end{array}$ & $\begin{array}{c}\text { Kelebihan } \\
\text { Debit } \\
\mathrm{m}^{3} / \mathrm{dt} \\
\end{array}$ & $\begin{array}{c}\text { Kekurangan } \\
\text { Debit } \\
\mathrm{m}^{3} / \mathrm{dt}\end{array}$ & $\begin{array}{c}\text { Kelebihan } \\
\text { Debit } \\
\mathrm{m}^{3} / \mathrm{dt} \\
\end{array}$ & $\begin{array}{c}\text { Kekurangan } \\
\text { Debit } \\
\mathrm{m}^{3} / \mathrm{dt}\end{array}$ & $\begin{array}{c}\text { Kelebihan } \\
\text { Debit } \\
\mathrm{m}^{3} / \mathrm{dt}\end{array}$ \\
\hline+90.14 & 4.409 & 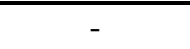 & 0.263 & 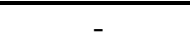 & 2.384 & 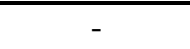 & 2.208 \\
\hline+89.14 & 4.314 & - & 0.168 & - & 2.289 & - & 2.114 \\
\hline+88.14 & 4.217 & - & 0.071 & - & 2.192 & - & 2.016 \\
\hline+87.14 & 4.118 & 0.028 & - & - & 2.093 & - & 1.917 \\
\hline+86.14 & 4.016 & 0.130 & - & - & 1.991 & - & 1.815 \\
\hline+85.14 & 3.911 & 0.235 & - & - & 1.886 & - & 1.711 \\
\hline+84.14 & 3.804 & 0.342 & - & - & 1.779 & - & 1.604 \\
\hline+83.14 & 3.694 & 0.452 & - & - & 1.669 & - & 1.493 \\
\hline+82.14 & 3.580 & 0.566 & - & - & 1.555 & - & 1.379 \\
\hline+80.70 & 3.360 & 0.786 & - & - & 1.335 & - & 1.160 \\
\hline
\end{tabular}


Lanjutan Tabel 5: Rekapitulasi Kelebihan dan Kekurangan Debit Dalam 1 Tahun Untuk 1 (Satu) Katup

\begin{tabular}{|c|c|c|c|c|c|c|c|c|c|}
\hline \multicolumn{2}{|c|}{ April: $3,671 \mathrm{~m}^{3} / \mathrm{dt}$} & \multicolumn{2}{|c|}{ Mei: $7,363 \mathrm{~m}^{3} / \mathrm{dt}$} & \multicolumn{2}{|c|}{ Juni: $6,773 \mathrm{~m}^{3} / \mathrm{dt}$} & \multicolumn{2}{|c|}{ Juli: $1,396 \mathrm{~m}^{3} / \mathrm{dt}$} & \multicolumn{2}{|c|}{$\begin{array}{c}\text { Agustus: } 1,592 \\
\mathrm{~m}^{3} / \mathrm{dt}\end{array}$} \\
\hline $\begin{array}{l}\text { Kekura- } \\
\text { ngan }\end{array}$ & $\begin{array}{l}\text { Kelebi } \\
\text { han }\end{array}$ & $\begin{array}{l}\text { Kekura- } \\
\text { ngan }\end{array}$ & $\begin{array}{c}\text { Kelebi } \\
\text { han }\end{array}$ & $\begin{array}{l}\text { Kekura- } \\
\text { ngan }\end{array}$ & $\begin{array}{l}\text { Kelebi } \\
\text { han }\end{array}$ & $\begin{array}{l}\text { Kekura- } \\
\text { ngan }\end{array}$ & $\begin{array}{l}\text { Kelebi } \\
\text { han }\end{array}$ & $\begin{array}{l}\text { Kekura- } \\
\text { ngan }\end{array}$ & $\begin{array}{c}\text { Kelebi } \\
\text { han }\end{array}$ \\
\hline Debit & Debit & Debit & Debit & Debit & Debit & Debit & Debit & Debit & Debit \\
\hline $\mathrm{m}^{3} / \mathrm{dt}$ & $\mathrm{m}^{3} / \mathrm{dt}$ & $\mathrm{m}^{3} / \mathrm{dt}$ & $\mathrm{m}^{3} / \mathrm{dt}$ & $\mathrm{m}^{3} / \mathrm{dt}$ & $\mathrm{m}^{3} / \mathrm{dt}$ & $\mathrm{m}^{3} / \mathrm{dt}$ & $\mathrm{m}^{3} / \mathrm{dt}$ & $\mathrm{m}^{3} / \mathrm{dt}$ & $\mathrm{m}^{3} / \mathrm{dt}$ \\
\hline- & 0.738 & 2.954 & - & 2.364 & - & - & 3.013 & - & 2.817 \\
\hline- & 0.643 & 3.049 & - & 2.459 & - & - & 2.918 & - & 2.722 \\
\hline- & 0.546 & 3.146 & - & 2.556 & - & - & 2.821 & - & 2.625 \\
\hline- & 0.446 & 3.245 & - & 2.655 & - & - & 2.721 & - & 2.526 \\
\hline- & 0.345 & 3.347 & - & 2.757 & - & - & 2.620 & - & 2.424 \\
\hline- & 0.240 & 3.451 & - & 2.861 & - & - & 2.515 & - & 2.319 \\
\hline- & 0.133 & 3.559 & - & 2.969 & - & - & 2.408 & - & 2.212 \\
\hline- & 0.022 & 3.669 & - & 3.079 & - & - & 2.297 & - & 2.102 \\
\hline 0.091 & - & 3.783 & - & 3.193 & - & - & 2.184 & - & 1.988 \\
\hline 0.311 & - & 4.002 & - & 3.412 & - & - & 1.964 & - & 1.768 \\
\hline
\end{tabular}

Lanjutan Tabel 5: Rekapitulasi Kelebihan dan Kekurangan Debit Dalam 1 Tahun Untuk 1 (Satu) Katup

\begin{tabular}{|c|c|c|c|c|c|c|c|}
\hline \multicolumn{2}{|c|}{ September: $3,231 \mathrm{~m}^{3} / \mathrm{dt}$} & \multicolumn{2}{|c|}{ Oktober: $3,349 \mathrm{~m}^{3} / \mathrm{dt}$} & \multicolumn{2}{|c|}{ November: $2,807 \mathrm{~m}^{3} / \mathrm{dt}$} & \multicolumn{2}{|c|}{ Desember: $3,377 \mathrm{~m}^{3} / \mathrm{dt}$} \\
\hline $\begin{array}{c}\text { Kekurang- } \\
\text { an Debit } \\
\mathrm{m}^{3} / \mathrm{dt} \\
\end{array}$ & $\begin{array}{c}\text { Kelebihan } \\
\text { Debit } \\
\mathrm{m}^{3} / \mathrm{dt} \\
\end{array}$ & $\begin{array}{c}\text { Kekurang- } \\
\text { an Debit } \\
\mathrm{m}^{3} / \mathrm{dt} \\
\end{array}$ & $\begin{array}{c}\text { Kelebihan } \\
\text { Debit } \\
\mathrm{m}^{3} / \mathrm{dt} \\
\end{array}$ & $\begin{array}{c}\text { Kekurang- } \\
\text { an Debit } \\
\mathrm{m}^{3} / \mathrm{dt}\end{array}$ & $\begin{array}{c}\text { Kelebihan } \\
\text { Debit } \\
\mathrm{m}^{3} / \mathrm{dt} \\
\end{array}$ & $\begin{array}{c}\text { Kekurang- } \\
\text { an Debit } \\
\mathrm{m}^{3} / \mathrm{dt} \\
\end{array}$ & $\begin{array}{c}\text { Kelebihan } \\
\text { Debit } \\
\mathrm{m}^{3} / \mathrm{dt} \\
\end{array}$ \\
\hline- & 1.178 & - & 1.060 & - & 1.602 & - & 1.032 \\
\hline- & 1.083 & - & 0.965 & - & 1.507 & - & 0.937 \\
\hline- & 0.986 & - & 0.868 & - & 1.410 & - & 0.840 \\
\hline- & 0.887 & - & 0.769 & - & 1.310 & - & 0.741 \\
\hline- & 0.785 & - & 0.667 & - & 1.209 & - & 0.639 \\
\hline- & 0.680 & - & 0.563 & - & 1.104 & - & 0.534 \\
\hline- & 0.573 & - & 0.455 & - & 0.997 & - & 0.427 \\
\hline- & 0.463 & - & 0.345 & - & 0.886 & - & 0.317 \\
\hline- & 0.349 & - & 0.231 & - & 0.773 & - & 0.203 \\
\hline- & 0.129 & - & 0.012 & - & 0.553 & 0.017 & - \\
\hline
\end{tabular}

Tabel 6: Rekapitulasi Kelebihan dan Kekurangan Debit Dalam 1 Tahun Untuk 2 (Dua) Katup

\begin{tabular}{cccccccc}
\hline & Debit & \multicolumn{2}{c}{ Januari : } & \multicolumn{2}{c}{ Februari: } & \multicolumn{2}{c}{ Maret: } \\
& Hitung & \multicolumn{2}{c}{$4,146 \mathrm{~m}^{3} / \mathrm{dt}$} & \multicolumn{2}{c}{$2,025 \mathrm{~m}^{3} / \mathrm{dt}$} & \multicolumn{2}{c}{ 2,201 $\mathrm{m}^{3} / \mathrm{dt}$} \\
\cline { 2 - 7 } Elevasi & $\begin{array}{c}\text { Intake } 2 \\
\text { Katup }\end{array}$ & $\begin{array}{c}\text { Kekurangan } \\
\text { Debit }\end{array}$ & $\begin{array}{c}\text { Kelebihan } \\
\text { Debit }\end{array}$ & $\begin{array}{c}\text { Kekurangan } \\
\text { Debit }\end{array}$ & $\begin{array}{c}\text { Kelebihan } \\
\text { Debit }\end{array}$ & $\begin{array}{c}\text { Kekurangan } \\
\text { Debit }\end{array}$ & $\begin{array}{c}\text { Kelebihan } \\
\text { Debit }\end{array}$ \\
& $\mathrm{m}^{3} / \mathrm{dt}$ & $\mathrm{m}^{3} / \mathrm{dt}$ & $\mathrm{m}^{3} / \mathrm{dt}$ & $\mathrm{m}^{3} / \mathrm{dt}$ & $\mathrm{m}^{3} / \mathrm{dt}$ & $\mathrm{m}^{3} / \mathrm{dt}$ & $\mathrm{m}^{3} / \mathrm{dt}$ \\
\hline \hline+90.14 & 8.818 & - & 4.672 & - & 6.793 & - & 6.617 \\
+89.14 & 8.628 & - & 4.482 & - & 6.603 & - & 6.428 \\
+88.14 & 8.434 & - & 4.288 & - & 6.409 & - & 6.234 \\
+87.14 & 8.235 & - & 4.089 & - & 6.210 & - & 6.035 \\
+86.14 & 8.032 & - & 3.886 & - & 6.007 & - & 5.831 \\
+85.14 & 7.823 & - & 3.677 & - & 5.798 & - & 5.622 \\
+84.14 & 7.608 & - & 3.462 & - & 5.583 & - & 5.408 \\
+83.14 & 7.388 & - & 3.242 & - & 5.362 & - & 5.187 \\
+82.14 & 7.160 & - & 3.014 & - & 5.135 & - & 4.959 \\
+80.70 & 6.721 & - & 2.575 & - & 4.696 & - & 4.520 \\
\hline
\end{tabular}


Lanjutan Tabel 6: Rekapitulasi Kelebihan dan Kekurangan Debit Dalam 1 Tahun Untuk 2 (Dua) Katup

\begin{tabular}{cccccccccc}
\hline \multicolumn{2}{c}{ April: $3,671 \mathrm{~m}^{3} / \mathrm{dt}$} & \multicolumn{2}{c}{ Mei: 7,363 $\mathrm{m}^{3} / \mathrm{dt}$} & \multicolumn{2}{c}{ Juni: $6,773 \mathrm{~m}^{3} / \mathrm{dt}$} & \multicolumn{2}{c}{ Juli: $1,396 \mathrm{~m}^{3} / \mathrm{dt}$} & \multicolumn{3}{c}{$\begin{array}{c}\text { Agustus: } 1,592 \\
\mathrm{~m}^{3} / \mathrm{dt}\end{array}$} \\
\hline $\begin{array}{c}\text { Kekura- } \\
\text { ngan }\end{array}$ & $\begin{array}{c}\text { Kelebi } \\
\text { han }\end{array}$ & $\begin{array}{c}\text { Kekura- } \\
\text { ngan }\end{array}$ & $\begin{array}{c}\text { Kelebi } \\
\text { han }\end{array}$ & $\begin{array}{c}\text { Kekura- } \\
\text { ngan }\end{array}$ & $\begin{array}{c}\text { Kelebi } \\
\text { han }\end{array}$ & $\begin{array}{c}\text { Kekura- } \\
\text { ngan }\end{array}$ & $\begin{array}{c}\text { Kelebi } \\
\text { han }\end{array}$ & $\begin{array}{c}\text { Kekura- } \\
\text { ngan }\end{array}$ & $\begin{array}{c}\text { Kelebi } \\
\text { han }\end{array}$ \\
$\mathrm{m}^{3} / \mathrm{dt}$ & $\mathrm{m}^{3} / \mathrm{dt}$ & $\mathrm{m}^{3} / \mathrm{dt}$ & $\mathrm{m}^{3} / \mathrm{dt}$ & $\mathrm{m}^{3} / \mathrm{dt}$ & $\mathrm{m}^{3} / \mathrm{dt}$ & $\mathrm{m}^{3} / \mathrm{dt}$ & $\mathrm{m}^{3} / \mathrm{dt}$ & $\begin{array}{c}\text { Debit } \\
\mathrm{m}^{3} / \mathrm{dt}\end{array}$ & $\begin{array}{c}\text { Debit } \\
\mathrm{m}^{3} / \mathrm{dt}\end{array}$ \\
\hline- & 5.147 & - & 1.455 & - & 2.045 & - & 7.422 & - & 7.226 \\
- & 4.957 & - & 1.265 & - & 1.855 & - & 7.232 & - & 7.036 \\
- & 4.763 & - & 1.071 & - & 1.661 & - & 7.038 & - & 6.842 \\
- & 4.564 & - & 0.873 & - & 1.463 & - & 6.839 & - & 6.643 \\
- & 4.361 & - & 0.669 & - & 1.259 & - & 6.636 & - & 6.440 \\
- & 4.152 & - & 0.460 & - & 1.050 & - & 6.427 & - & 6.231 \\
- & 3.937 & - & 0.246 & - & 0.836 & - & 6.212 & - & 6.016 \\
- & 3.716 & - & 0.025 & - & 0.615 & - & 5.991 & - & 5.795 \\
- & 3.489 & 0.203 & - & - & 0.387 & - & 5.764 & - & 5.568 \\
- & 3.050 & 0.642 & - & 0.052 & - & - & 5.325 & - & 5.129 \\
\hline
\end{tabular}

Lanjutan Tabel 6: Rekapitulasi Kelebihan dan Kekurangan Debit Dalam 1 Tahun Untuk 2 (Dua) Katup

\begin{tabular}{cccccccc}
\hline \multicolumn{2}{c}{ September: $3,231 \mathrm{~m}^{3} / \mathrm{dt}$} & \multicolumn{2}{c}{ Oktober: $3,349 \mathrm{~m}^{3} / \mathrm{dt}$} & \multicolumn{2}{c}{ November: $2,807 \mathrm{~m}^{3} / \mathrm{dt}$} & \multicolumn{2}{c}{ Desember: $3,377 \mathrm{~m}^{3} / \mathrm{dt}$} \\
\hline $\begin{array}{c}\text { Kekurang- } \\
\text { an Debit } \\
\mathrm{m}^{3} / \mathrm{dt}\end{array}$ & $\begin{array}{c}\text { Kelebihan } \\
\text { Debit } \\
\mathrm{m}^{3} / \mathrm{dt}\end{array}$ & $\begin{array}{c}\text { Kekurang- } \\
\text { an Debit } \\
\mathrm{m}^{3} / \mathrm{dt}\end{array}$ & $\begin{array}{c}\text { Kelebihan } \\
\text { Debit } \\
\mathrm{m}^{3} / \mathrm{dt}\end{array}$ & $\begin{array}{c}\text { Kekurang- } \\
\text { an Debit } \\
\mathrm{m}^{3} / \mathrm{dt}\end{array}$ & $\begin{array}{c}\text { Kelebihan } \\
\text { Debit } \\
\mathrm{m}^{3} / \mathrm{dt}\end{array}$ & $\begin{array}{c}\text { Kekurang- } \\
\text { an Debit } \\
\mathrm{m}^{3} / \mathrm{dt}^{2}\end{array}$ & $\begin{array}{c}\text { Kelebihan } \\
\text { Debit } \\
\mathrm{m}^{3} / \mathrm{dt}\end{array}$ \\
\hline- & 5.587 & - & 5.469 & - & 6.011 & - & 5.441 \\
- & 5.397 & - & 5.279 & - & 5.821 & - & 5.251 \\
- & 5.203 & - & 5.085 & - & 5.627 & - & 5.057 \\
- & 5.004 & - & 4.887 & - & 5.428 & - & 4.858 \\
- & 4.801 & - & 4.683 & - & 5.224 & - & 4.655 \\
- & 4.592 & - & 4.474 & - & 5.016 & - & 4.446 \\
- & 4.377 & - & 4.260 & - & 4.801 & - & 4.231 \\
- & 4.156 & - & 4.039 & - & 4.580 & - & 4.010 \\
- & 3.929 & - & 3.811 & - & 4.353 & - & 3.783 \\
\hline
\end{tabular}

Perhitungan kelebihan dan kekurangan debit untuk 1 dan 2 katup dengan menggunakan variasi debit setiap bulannya dapat disimpulkan bahwa pada pola operasi 1 katup terdapat kekurangan debit pada bulan Januari, April serta Desember. Untuk pola operasi 2 katup terdapat kekurangan debit pada bulan Mei dan Juni.

\subsection{Penentuan Peredam Energi}

Untuk menentukan menggunakan tipe peredam energi yang digunakan serta mendapatkan nilai $\mathrm{Y}_{1}$ (kedalaman air awal loncat) dan $\mathrm{Y}_{2}$ (kedalaman air di atas ambang) tersaji pada tabel 7.

Tabel 7: Menentukan Tipe Peredam Energi dan Nilai $Y_{1}$ serta $Y_{2}$

\begin{tabular}{ccccccccc}
\hline \multicolumn{2}{c}{ Q } & & & & & & & \\
$\begin{array}{c}\text { Intake 1 } \\
\text { Katup } \\
\mathrm{m}^{3} / \mathrm{dt}\end{array}$ & $\begin{array}{c}\text { Intake 2 } \\
\text { Katup } \\
\mathrm{m}^{3} / \mathrm{dt}\end{array}$ & $\mathrm{V}$ & $\mathrm{Y} 1$ & $\mathrm{Fr}$ & $\mathrm{Y}_{2}$ & $\begin{array}{c}\text { Ketentuan } \\
\text { Fr }\end{array}$ & Kolam Olak Tipe & $\begin{array}{c}\text { Debit } \\
\text { Kebutuhan }\end{array}$ \\
\hline 4.409 & 8.818 & 8.665 & 0.900 & 2.916 & 3.289 & $2,5-4,5$ & Ogee IV & 3.940 \\
\hline
\end{tabular}

Berdasarkan tabel 7, diperoleh nilai $\mathrm{Y}_{1}=0,900 \mathrm{~m}, \mathrm{Y}_{2}=3,289 \mathrm{~m}$ untuk itu dibutuhkan kolam olak yang digunakan adalah USBR tipe Ogee IV di dasarkan pada ketentuan Froude diantara 2,5-4,5 dengan $\operatorname{Fr}=2,916$. 


\subsection{Perhitungan Tail Water Level Pada Escape Channel}

Untuk mengetahui nilai $\mathrm{Y}_{3}$ dan elevasi pada escape channel dilakukan dengan menggunakan rating curve. Dengan data yang diketahui elevasi dasar escape channel $+66,31, \mathrm{~b}=15 \mathrm{~m}$ (sesuai kondisi eksisting), $\mathrm{m}=1 \mathrm{~m}$ (kemiringan talud), $\mathrm{I}=0,001$ (Slope) serta nilai $\mathrm{n}=0,014$ (koefisien manning untuk beton). Hasil rating curve dapat dilihat pada tabel 8.

Tabel 8: Hasil Nilai Y 3 Untuk 1 (Satu) dan 2 (Dua) Katup

\begin{tabular}{lccccccccc}
\hline & $\begin{array}{c}\text { Debit } \\
\mathrm{m}^{3} / \mathrm{dt}\end{array}$ & $\begin{array}{c}\mathrm{Y}_{3} \\
\mathrm{~m}\end{array}$ & El. Muka Air & $\begin{array}{c}\mathrm{A} \\
\mathrm{m}\end{array}$ & $\begin{array}{c}\mathrm{P} \\
\mathrm{m}\end{array}$ & $\begin{array}{c}\mathrm{R} \\
\mathrm{m}\end{array}$ & $\begin{array}{c}\mathrm{V} \\
\mathrm{m} / \mathrm{dt}\end{array}$ & Fr & Keterangan \\
\hline \hline 1 Katup & 4.409 & 0.208 & 66.708 & 3.219 & 6.818 & 0.196 & 0.569 & 0.261 & Sub Kritis \\
2 Katup & 8.818 & 0.415 & 66.915 & 6.438 & 13.636 & 0.392 & 1.138 & 0.522 & Sub Kritis \\
\hline
\end{tabular}

Berdasarkan debit yang digunakan dari pola operasi pada perhitungan nilai $\mathrm{Y}_{3}$ di dapatkan hasil untuk 1 katup $\mathrm{Y}_{3}$ sebesar 0,208 $\mathrm{m}$ dan 2 katup $\mathrm{Y}_{3}$ sebesar 0,415 $\mathrm{m}$ dengan aliran sub kritis. Selanjutnya melakukan perhitungan untuk mengetahui elevasi muka air pada $\mathrm{Y}_{2}$ dan elevasi muka air pada escape channel seperti tersaji pada tabel 9.

Tabel 9: Perhitungan Elevasi $Y_{2}$ dan $Y_{3}$ Untuk 1 (Satu) dan 2 (Dua) Katup

\begin{tabular}{cccccc}
\hline & $\begin{array}{c}\text { Debit } \\
\mathrm{m}^{3} / \mathrm{dt}\end{array}$ & $\begin{array}{c}\mathrm{Y}_{2} \\
\mathrm{~m}\end{array}$ & $\begin{array}{c}\text { El. Muka Air } \\
\left(\mathrm{Y}_{2}\right)\end{array}$ & $\begin{array}{c}\text { El. Muka Air } \\
(\text { Escape Channel) }\end{array}$ & $\begin{array}{c}\Delta \mathrm{H} \\
\mathrm{m}\end{array}$ \\
\hline \hline 1 Katup & 4.409 & 3.289 & 66.739 & 66.518 & 0.221 \\
2 Katup & 8.818 & 3.289 & 66.739 & 66.725 & 0.014 \\
\hline
\end{tabular}

Hasil perhitungan tabel 9 menghasilkan nilai $\mathrm{Y}_{2}$ dan $\mathrm{Y}_{3}$ serta diketahui elevasi dasar saluran kolam olak sebesar $+63,45$, maka di dapatkan nilai elevasi muka air untuk $\mathrm{Y}_{2}(1 \mathrm{Katup})=+66,739$ dan $\mathrm{Y}_{2}(2$ Katup $)=+66,739$. Untuk elevasi muka air escape channel $(1$ Katup $)=+66,518$ dan $(2$ Katup $)=$ $+66,725$.

\subsection{Perhitungan Pukulan Air (Water Hammer) Pada Bangunan Intake}

Water hammer dilakukan untuk mengetahui ada tidaknya pukulan air pada pipa tertutup. Hasil perhitungan diperoleh dengan menghitung Ec (campuran antara Ep dan Eb), perambatan gelombang (C), waktu yang diperlukan gelombang kembali sampai katup (t), dan tekanan pukulan air maksimal $(\mathrm{P})$.

Tabel 10: Hasil Perhitungan Water Hammer

\begin{tabular}{cccc}
\hline$\frac{1}{E c}$ & $\mathrm{C}$ & $\mathrm{t}$ & $\mathrm{P}$ \\
$\mathrm{m} / \mathrm{dt}$ & $\mathrm{dt}$ & $\mathrm{N} / \mathrm{m}^{2}$ \\
\hline \hline $1.80 \times 10^{9}$ & 1341.641 & 0.119 & $1.19 \times 10^{7}$ \\
\hline
\end{tabular}

Berdasarkan perhitungan water hammer diatas dapat disimpulkan bahwa pada pipa saluran intake terdapat pukulan air maksimum namun sangat kecil. Sehingga, perlu adanya pencegahan timbulnya pukulan air yaitu salah satunya dengan cara memasang rongga udara.

\subsection{Perhitungan Ventilasi Pada Bangunan Intake}

Hasil perhitungan ventilasi diperoleh dengan menghitung luas penampang aliran yang melintasi pintu (A), debit (Q) dan kecepatan aliran (v) yang melintasi pintu, bilangan Froude (Fr), volume udara (Qa), serta luas penampang ventilasi (Aa) dan diameter pipa ventilasi (D). 
Tabel 11: Hasil Perhitungan Ventilasi

\begin{tabular}{ccccccc}
\hline $\begin{array}{c}\mathrm{A} \\
\mathrm{m}^{2}\end{array}$ & $\begin{array}{c}\mathrm{Q} \\
\mathrm{m}^{3} / \mathrm{dt}\end{array}$ & $\begin{array}{c}\mathrm{V} \\
\mathrm{m} / \mathrm{dt}\end{array}$ & $\mathrm{Fr}$ & $\begin{array}{c}\mathrm{Qa} \\
\mathrm{m}^{3} / \mathrm{dt}\end{array}$ & $\begin{array}{c}\text { Aa } \\
\mathrm{m}^{2}\end{array}$ & $\begin{array}{c}\mathrm{D} \\
\mathrm{m}\end{array}$ \\
\hline 0.960 & 17.225 & 17.943 & 6.404 & 2.891 & 0.096 & 0.349 \\
\hline
\end{tabular}

Dari hasil perhitungan diatas di dapat diameter pipa sebesar $0,349 \mathrm{~m} \approx 0,350 \mathrm{~m}$, maka di gunakan pipa berdiameter $35 \mathrm{~cm}$.

\section{Kesimpulan}

Berdasarkan studi yang sudah dilakukan didapatkan kesimpulan bahwa sebelum melakukan routing untuk pola operasi perlu diketahui kehilangan tingi yang terjadi sepanjang pipa dari mulai inlet sampai dengan outlet. Nilai kehilangan tinggi yang dihasilkan selanjutnya digunakan untuk menghitung pola operasi 1 (satu) dan 2 (dua) katup guna mampu mengairi lahan sawah. Pada routing pola operasi, katup dibuka 1 katup terlebih dahulu dimana terdapat debit yang tidak memenuhi kebutuhan disawah maka dilakukan pembukaan 2 katup yang seluruhnya memenuhi dengan debit kebutuhan. Saluran pengarah akhir melakukan perhitungan menggunakan rating curve sehingga diperoleh tipe kolam olak yang digunakan dan aliran air yang melewatinya.

\section{Daftar Pustaka}

[1] F. e. al, "Produktivitas Air Dalam Pengelolaan Sumber Daya Air Pertanian di Indonesia," Jurnal Spasial, vol. 3, p. 66, 2018.

[2] K. PT. Wecon, Laporan Teknis Bendungan Semantok, Nganjuk, 2019.

[3] B. o. Reclamation, Design of Small Dam, Washington: Water Resources Technical Publication, 1987.

[4] P. P. d. P. S. D. A. d. Konstruksi, Desain Bangunan Pelengkap Pelatihan Perencanaan Bendungan Tingkat Dasar, Bandung: Yayasan Penerbit PU, 2017.

[5] D. J. P. Tinggi, Hidrolika I, Bandung: TEDC, 1982.

[6] G. W. Bruner, HEC-RAS, River Analysis System Hydraulic Reference Manual, United States: Hydrologic Engineering Center, 2016.

[7] e. a. Henry T. Falvey, CIVITATION IN CHUTES AND SPILLWAYS, Denver, Colorado 80225: United States Departement Of The Interior, 1990.

[8] S. \&. k. T. D. Sosrodarsono, Bendungan Tipe Urugan, Jakarta: Pradnya Paramita, 2016.

[9] R. K. \&. F. J. Linsley, Teknik Sumber Daya Air Jilid 2 Edisi Ketiga Terjemahan Djoko Sasongko, Jakarta: Erlangga, 1986.

[10] A. L. Simon, Hydraulics Fourth Edition, USA: Prentice Hall, Inc, 1996. 